\title{
Gender Roles and the Education Gender Gap in Turkey
}

\author{
Asena Caner ${ }^{1} \cdot$ Cahit Guven $^{2} \cdot$ Cagla Okten $^{3}$. \\ Seyhun Orcan Sakalli ${ }^{4}$
}

Accepted: 23 October 2015/Published online: 3 November 2015

(C) Springer Science+Business Media Dordrecht 2015

\begin{abstract}
Using nationally representative data on individual subjective views on gender roles, we examine the gender gap in educational achievement in Turkey and show that the cultural bias against the education of girls is a fundamental factor behind their low educational attainment in socially conservative societies. The 1997 education reform in Turkey extended compulsory schooling from 5 to 8 years. Using the reform as a natural experiment, we investigate the impact of the reform on the effects of mothers' traditional views in determining children's educational attainment. We find that the reform helped reduce school dropout rates across the country. Nevertheless, regardless of the mother's view on gender roles, the reductions in school dropout rates were similar for boys and girls, failing to eliminate the gender gap against girls. Turkey is an excellent environment to study the effects of societal gender roles since it combines modernity with traditionalism and displays a wide spectrum of views on gender roles. It is also one of the few developing countries where a gender gap to the detriment of females still exists in educational achievement.
\end{abstract}

Keywords Education gender gap - Gender roles · Compulsory schooling · Turkey

Asena Caner

acaner@etu.edu.tr

Cahit Guven

cahit.guven@deakin.edu.au

Cagla Okten

cokten@bilkent.edu.tr

Seyhun Orcan Sakalli

seyhun-orcan.sakalli@psemail.eu

1 TOBB University of Economics and Technology, Ankara, Turkey

2 Department of Economics, Deakin Business School, Deakin University, Geelong, Australia

3 Bilkent University, Ankara, Turkey

4 Paris School of Economics, Paris, France 


\section{Introduction}

In Turkey, $7 \%$ of girls between ages 8 and 12 never make it to school, compared with $2 \%$ of boys. By age 15, female enrolment is almost $20 \%$ points below male enrolment (UNESCO 2010). In tertiary education, as of 2009, 77 women were enrolled for each 100 men, which is substantially lower than the European Union average of 124 women for every 100 men in the same year (Eurostat 2012). Even among developing countries, Turkey is one of the few countries where a substantial gender gap in education to the detriment of girls still exists (Pekkarinen 2012).

Differences in gender roles have been offered as an explanation for observed gender differences in educational and labor market outcomes (Bertrand 2010; Fortin 2005). Many believe that views on gender roles are largely determined early in childhood. In some countries, children grow up in an environment in which son preference is strong (see, for example, Zhang et al. (2007) for China, Stash and Hannum (2001) for Nepal). Even in countries that are not typically considered to have patrilineal family systems, female labor market outcomes may depend on parental views on gender roles (see, for example, Vella (1994) for Australia, Farre and Vella (2012) for the US).

In many parts of the world, educational outcomes of women have been improving. In the US, women started outnumbering men in graduating from 4-year colleges in the 1980s (Goldin et al. 2006). The number of countries where women have more years of education than men increased from 11 in 1950 to 43 in 2010 in a sample of 146 countries. Female enrollment in tertiary education is higher than male enrollment in all of the OECD countries with the exception of Japan, South Korea, Switzerland, and Turkey, and in some large non-OECD countries such as the Philippines, Iran, and Thailand (Pekkarinen 2012). In developing countries, girls on average have equal or greater schooling attainment than boys, despite lingering gender gaps in school entry favoring boys (Grant and Behrman 2010). In Thailand, girls are currently more likely to be enrolled in secondary school than boys, even in agricultural communities, which has been attributed to the absence of a strong gender preference for boys (Korinek and Punpuing 2012).

In socially conservative parts of Turkey, a traditional view on gender roles prevails. Indeed, several studies that have conducted face-to-face interviews with parents, teachers and local officials in Turkey, report conservative views against girls' education as a major impediment. In four cities of the Black Sea region with low enrollment rates for girls, a concern for girls' chastity, need for girls' labor at home, preference for religious education and early marriages were presented as the main reasons for not educating girls (Alat and Alat 2011). In a traditional and low-income city (Van), parents stated that low income and social pressure against sending girls to mixed sex schools as the most important reasons for keeping girls out of school. Interestingly, all families in the sample who do not educate their daughters educate their sons (İlhan Tunç 2009). A study that used data from the Turkish Family Structure Survey, conducted in 1988, found that patriarchal family beliefs and practices discourage the education of girls beyond primary school and that the effect is independent of the effects of macro-structural variables (such as region, urbanization level, labor market conditions) and family background variables (such as parental education and employment status, household income and household size) (Rankin and Aytaç 2006). Conservative views on gender roles are reflected also in popular discourse. Recently, the Turkish Minister of Health has commented about motherhood being the only acceptable career for women (Hurriyet Daily News 2015).

With a culturally diverse population, Turkey provides an excellent environment to study the interaction between views on gender roles and education and the effects of education 
policies on this interaction. The country combines modernity with traditionalism and it displays a wide spectrum of views. ${ }^{1}$

We start our analyses by documenting school dropout rates across educational stages and examine their association with views on gender roles using nationally representative data from the Turkish Demographic and Health Surveys (TDHS). For policymakers, it is vital to know at which stages of education the gender gap arises and is the most significant. Using data on individual subjective views on gender roles, we find that sons and daughters of women who have a traditional view on gender roles are more likely to drop out during and after primary school, and that the effects are stronger for daughters. Therefore, traditional gender roles interfere with girls' education very early in life.

Next, we examine the impact of an extension in the duration of compulsory schooling on the adverse effects of mother's traditional view in determining children's educational attainment. The 1997 education reform in Turkey increased compulsory schooling from 5 to 8 years. Using the reform as a natural experiment, we show that although the reform helped reduce school dropout rates across the country, reductions in school dropout rates were similar for boys and girls within the group of children whose mothers have a traditional view on gender roles. Therefore, we show that the policy definitely benefitted children, but it failed to eliminate the educational gender gap against girls.

There are only two studies analyzing the effects of the education reform on gender gap in education in Turkey. These studies do not consider the association of gender gap in education with views and attitudes on gender roles - the focus of our study. In the first study, the reform has been found to substantially reduce the urban-rural gap in educational attainment, but not the gender gap (Kirdar et al. 2013). The second study by Gulesci and Myersson (2013) finds that the reform resulted in a 1-year increase in years of schooling on average among women, but did not increase schooling among men, thereby reducing the gender gap. ${ }^{2}$ Hence, the two studies that analyze the effect of the reform on gender gap in education find conflicting results. Our study considers the heterogeneity in social preferences towards educating girls in the Turkish society and aims to analyze the differential impact of the reform for children with mothers holding different views on gender roles. Hence, our study also contributes to reconcile the different findings in the literature about the effect of the education reform on the educational gender gap by considering the differential impact of the reform for households with different social preferences.

Next, we provide a setting section where we present background information on the education system in Turkey and the 1997 compulsory education reform. Section 3 describes the conceptual and empirical framework. Section 4 presents results. Section 5 discusses the results and some measurement issues. Section 6 concludes.

\footnotetext{
1 A cross-country comparison has been made by the authors using the European Social Survey and the World Values Survey data, with the purpose of comparing the variation within Turkey to the variation across country averages. These surveys ask respondents questions on gender inequality. In particular, one question asks whether they agree with the statement "when jobs are scarce, men should have more right to a job than women" (agree: 1, disagree: 0). The regional (NUTS-1 level) averages of the indicator in Turkey vary between 3.22 in the most gender equal region and 4.12 in the most unequal region. By comparison, the average value of the indicator is about 3.23 in Chile, Romania, Spain and Great Britain, about 3.48 in China and Czech Republic, 3.59 in Russia, 3.78 in India and about 4 in Saudi Arabia and Algeria. The indicator ranges from 2.20 in Colombia and El Salvador) to 4.62 in Egypt and Iraq).

2 Dinçer et al. (2013) analyze the effect of education reform on fertility and children's health and find that the reform has had a substantial positive effect on girls' schooling in their first stage regression. They do not question the effect of the reform on the gender gap.
} 


\section{The Setting}

\subsection{The Education System in Turkey}

The Ottoman Empire, created by Turkish tribes in Anatolia, was a Sunni Islamic state that reigned during 1299-1923 over a large territory including modern day Turkey. The famous Tanzimat-era Education Regulation of 1869 (Maarif Nizamnamesi), the blue-print for the Empire's first centrally organized and controlled network of schools, was conceptualized during the reign of Sultan Abdulaziz (1861-76), but largely implemented during the reign of Sultan Abdulhamid II (1876-1909). Hamidian government attempted to construct a specifically Ottoman system of public education with a strong Islamic reference. Through a policy of linguistic Turkification and religious Sunnification, the state attempted to homogenize a citizenry loyal to the central authority (Herrera 2004). In primary schools, girls and boys commonly attended the classes together, but girls and boys sat at different desks inside one room. In addition to this, there were schools where only girls or only boys attended (Sonmez 2013).

Following World War I, the huge conglomeration of territories and peoples that formerly comprised the Ottoman Empire was divided into several new states. Turkish War of Independence (1919-1922), initiated by Mustafa Kemal Ataturk and his colleagues in Anatolia, resulted in the establishment of the modern Republic of Turkey in 1923, with Ataturk as its first president. At that time, $90 \%$ of the population was illiterate. The new republic established a secular education system and replaced the Arabic alphabet with the Turkish alphabet derived from the Latin alphabet.

\subsection{Compulsory Schooling in Turkey}

In Turkey, prior to 1997, the students were subject to a $5+3+3$ education system with only 5 years of compulsory primary education, followed by 3 years of junior high and 3 years of high school. With a law change in 1997, compulsory education was increased from five to 8 years by merging the first two levels. The 1997 8-year compulsory education enforcement law (Law no. 4306) and its implementation are discussed in several papers (Kirdar et al. 2013; Gulesci and Meyersson 2013; Kirdar et al. 2012; Dulger 2004); therefore we present only the main points here.

The new law extended compulsory schooling from 5 years (primary school) to 8 years (primary and junior high school), thereby raising the school leaving age from 11 to 14 . The law did not specify the ages or birth-cohorts of children it targets. Instead, it required that as of the beginning of the 1997-1998 school year all children enrolled in grades 1-5, and all children who started school in the future, remain in school through completion of the eighth grade (Dulger 2004). In Turkey, children typically start school at age 6, so we can infer that cohorts born in or after 1987 were subject to the education reform.

To meet the expected increase in demand, the law established a temporary set of earmarked taxes targeted to finance the expansion of schooling. These new taxes raised US $\$ 2$ billion in new revenues to support the cost of buildings, teachers and educational materials. The Ministry of National Education constructed 103,983 new basic education classrooms during 1997-2001, raising the total stock to 264,776 (Dulger 2004). During 1996-2003, 103,000 additional primary school teachers were hired, creating a $36 \%$ increase (Dinçer et al. 2013). In order to accommodate the children living in rural areas far away from existing schools, transportation was arranged. The reform led to a substantial 
increase in the number of students in primary school between the 1996/97 and the 2000/01 school years, by around $21 \%$ from 8.65 million to 10.48 million (education statistics are available at http://sgb.meb.gov.tr).

Sometimes, the insufficient supply of education for girls is a reason for gender differences in educational attainment. In countries where most schools are single-sex, the problem of access to schools can in fact be an issue for girls (Alderman et al. 1996). An advantage of studying Turkey is that its mixed-sex education system enables us to control for the effect of resource availability at the regional level on the gender gap in education. Furthermore, with the extension of compulsory schooling, the government made major improvements in schooling infrastructure as mentioned above. Therefore, in our study resource availability can be assumed to influence the two sexes in the same manner, thereby not show up as an explanatory factor behind the observed gender gap in education. In our case, the crucial factor in determining attainment is the traditional view of parents that acts as a barrier against female education, not school availability.

The reform provides us with an ideal natural experiment, since it varied the number of years of schooling without significant curriculum changes. It created an external shock on the educational attainment of children since it suddenly and unexpectedly changed the duration of compulsory schooling. The law change was made rather abruptly, before much discussion in advance, and was immediately put into effect. Some analysts write that at the time the political climate was ripe for a change, therefore the politicians did not want to miss the opportunity (Dulger 2004). For this study, it is in fact fortunate that the change was sudden and the households did not have the time to make plans against the change, since it makes it easier to defend using the reform as an instrument for educational attainment of the children.

Education statistics prior to 1998 show us the vast gender gap in educational attainment. In 1988, 16 year-old girls in western, central or northern Turkey were 1.5-3 times more likely to graduate from junior high school compared to girls in the least developed east region; for boys, no significant regional differences were observed. Furthermore, girls were found to be less likely to finish junior high school, if their fathers believed in sex segregation or that wives are only good for housework (Aytac and Rankin 2004). A study, based on 1994 data, reports higher inequality in female enrollment rates across provinces compared to inequality in total enrollment rates, at all levels of schooling (Tansel and Gungor 2000). In 1998, more than $50 \%$ of the girls aged 13-14 were out of school, compared to one-third of the boys; about $16 \%$ of girls aged 9-11 were out of school, compared to $7 \%$ of boys (Smits and Hoşgör 2006).

In countries where laws are strictly enforced and the infrastructure is available to keep track of school-aged children, it is not surprising that compulsory education positively influences educational outcomes. Indeed, a sizable literature on compulsory schooling laws finds that the introduction or extension of such laws improves educational attainment. The studies are usually on developed countries. ${ }^{3}$ When enforcement or infrastructure is imperfect, it is likely that some school-age children will not attend school. The educational gender gap in Turkey has declined since 1998, but a gap to the detriment of girls still exists. It has been reported that boys are $16 \%$ more likely than girls to complete higher education (2006 data) (Hisarciklilar et al. 2010). Although 8 years of primary education has been compulsory since 1997, about 640,000 children of primary school age (6-14), $60 \%$ of whom were girls, were out of school in 2007 (UNESCO 2010). Turkey has achieved universal primary education, but only in the modern western part of the country (Alat and Alat 2011).

\footnotetext{
3 Such as the US (Angrist and Krueger 1991; Acemoglu and Angrist 2001), Taiwan (Chou et al. 2010), Britain and Northern Ireland (Oreopoulos 2006), Britain (Devereux and Hart 2010), Germany (Kemptner et al. 2011), the US and Norway (Black et al. 2008), and 12 European countries (Brunello et al. 2009).
} 


\section{Methodology}

\subsection{Conceptual Framework}

In this study, we mainly test the following hypotheses about the Turkish education system:

Hypothesis 1 A female child has a lower educational attainment than a male child, on average.

Hypothesis 2 The effect of a mother's views related to gender roles on the educational attainment of her child varies by the gender of the child. In particular, daughters of women with a traditional view achieve lower educational attainment compared to the sons of women with a similar view. On the other hand, when mothers have a non-traditional view, sons and daughters achieve similar levels of education.

Hypothesis 3 Extending the duration of compulsory schooling by a law change in 1997 has helped reduce the adverse effects of a traditional view by closing the educational gap between boys and girls whose mothers hold traditional views.

\subsection{Empirical Framework}

In the first set of analyses, we test our first two hypotheses. We estimate the following equation using the ordinary least squares (OLS) technique:

$$
S_{i j}=\alpha_{0}+\alpha_{1} \text { Traditional }_{i j}+\alpha_{2} \text { Female }_{i j}+\alpha_{3} \text { Traditional }_{i j} \times \text { Female }_{i j}+\alpha_{4} X_{i j}+\alpha r_{j}+\omega_{i j},
$$

where $S_{i j}$ is a dummy variable that takes value of 1 if child $i$ residing in region $j$ dropped out of school during or after a certain level of educational attainment. Traditional $i_{i j}$ is a measure of mother's views on gender roles. We discuss how we construct this variable in the data section. Female $_{i j}$ is an indicator variable that takes value of 1 if child $i$ is female, 0 otherwise. Traditional $_{i j} \times$ Female $_{i j}$ is the interaction term. The estimate of $\alpha_{3}$ measures the effect of having a mother with a traditional view on the probability of dropping out of school for a girl compared to a boy. The vector of controls, $X_{i j}$, includes number of siblings, birth order, age and age-squared of the child, age and age-squared of the mother, parental education, mother tongue of the father and mother, wealth quintile (poorest, poorer, middle, richer, richest) and type of residence (urban, rural) of the household. Moreover, $r_{j}$ is the set of region dummies (West, South, Central, North, and East) that control for cross-regional differences. Standard errors are clustered at the mother level.

In the second set of analyses, we test our third hypothesis and estimate the impact of the 1997 education reform. We estimate Eq. (2) by using the OLS technique:

$$
\begin{aligned}
S_{i j}= & \beta_{0}+\beta_{1} \text { Traditional }_{i j}+\beta_{2} \text { Female }_{i j}+\beta_{3} \text { Traditional }_{i j} \times \text { Female }_{i j}+\beta_{4} \text { Postreform }_{i j} \\
& +\beta_{5} \text { Traditional }_{i j} \times \text { Postreform }_{i j}+\beta_{6} \text { Female }_{i j} \times \text { Postreform }_{i j}+\beta_{7} \text { Traditional }_{i j} \\
& \times \text { Female }_{i j} \times \text { Postreform }_{i j}+\beta_{8} X_{i j}+\beta r_{j}+u_{i j},
\end{aligned}
$$

where $S_{i j}$ Traditional $_{i j}$, Female $_{i j}$ and $r_{j}$ are defined as in Eq. (1). The new dummy variable, Postreform $_{i j}$, takes value of 1 if child $i$ in region $j$ belongs to one of the post-reform birth cohorts (those who are born after 1986) and 0 otherwise. The vector of controls, $X_{i j}$, includes number of siblings, birth order, age and age-squared of the mother, parental 
education, mother tongue of the father and mother, wealth quintile (poorest, poorer, middle, richer, richest) and type of residence (urban, rural) of the household. Standard errors are, as in Eq. (1), clustered at the mother level. The estimate of $\beta_{4}$ measures the effect of the reform on boys with non-traditional mothers (when traditional $=0$ and female $=0$ ). $\beta_{4}+\beta_{5}$ measures the effect of the reform on boys whose mothers hold traditional views. $\beta_{4}+\beta_{5}+\beta_{6}+\beta_{7}$ will give the effect of the reform on girls with mothers holding traditional views. Hence testing the significance of $\beta_{6}+\beta_{7}$ will be a test of our third hypothesis-whether the reform had a different effect on girls versus boys when their mothers hold traditional views.

\section{Data and Descriptive Statistics: Turkey Demographic and Health Surveys (TDHS)}

Data on views about gender roles come from the Turkish Demographic and Health Surveys (hereafter TDHS) (Institution of Population Studies; Hacettepe University; Macro International Inc. 1999; Institution of Population Studies; Hacettepe University; Ministry of Health (Turkey) 2004). TDHS are representative at the national level and also at the level of five major regions of the country (the West, South, Central, North, and East). The evermarried women module of TDHS provides data for a wide range of monitoring and impact evaluation indicators related to population, health, nutrition, women's beliefs and attitudes, and children's educational attainment.

For our analyses we choose to use the 1998 and 2003 rounds of the TDHS, because we would like to study the time period that is close to the 1997 education reform and thereby prevent time trends in the views on gender roles from confounding our results.

In the TDHS, the respondents are asked questions that aim to recover views on how power should be distributed across genders in different spheres of life. In particular, the respondents are asked whether they agree with the following statements: (1) "Men are wiser than women"; (2) "A man can beat his wife"; (3) "A woman should not argue with her husband"; (4) "It is better for a male child to have education than a female child"; (5) "Important decisions in the household should be made by men". Responses to all questions are coded as agree $=1$ and disagree $=0$.

We construct two alternative measures of views on gender roles. It is indeed an advantage of our data that we have a specific question on the respondents' preferences for the education of boys versus girls. First, we focus on statement (4) and create an indicator variable that takes the value of 1 if the mother of child $i$ agrees that it is better for a male child to have education than a female child, and 0 otherwise. We refer to this variable as the "traditional view indicator". When the traditional view indicator is equal to 1 , we refer to the mother as a mother with a traditional view. In our baseline analyses we use the indicator as our measure of mother's views on gender roles.

Secondly, we construct an alternative measure by using principal component analysis of all five statements on views on gender roles. We refer to this alternative measure as the "traditional view scale variable". In the discussion section, we explain whether our results are affected by the way in which we define "traditional view".

Table 1 describes our measures for mother's views on gender roles, educational outcome variables and control variables used in the regression analyses. Column 1 presents descriptive statistics in TDHS 1998 for children in ages 12-18 living in the same household as the mother. This is the main sample used in the estimation of Eq. (1). We restrict 
Table 1 Descriptive statistics

\begin{tabular}{|c|c|c|c|c|}
\hline & \multicolumn{2}{|l|}{ (1) } & \multicolumn{2}{|l|}{ (2) } \\
\hline & \multicolumn{2}{|c|}{1998 data } & \multicolumn{2}{|c|}{2003 data } \\
\hline & Mean & $\begin{array}{l}\text { Standard } \\
\text { deviation }\end{array}$ & Mean & $\begin{array}{l}\text { Standard } \\
\text { deviation }\end{array}$ \\
\hline Completed primary school & 0.91 & 0.29 & 1.00 & 0.00 \\
\hline Dropout after primary school & 0.33 & 0.47 & 0.17 & 0.38 \\
\hline Completed junior high school & 0.38 & 0.49 & 0.80 & 0.40 \\
\hline Dropout after junior high school & 0.13 & 0.34 & 0.18 & 0.39 \\
\hline Traditional view indicator & 0.29 & 0.46 & 0.20 & 0.40 \\
\hline Traditional view scale & 1.50 & 1.47 & 1.15 & 1.41 \\
\hline Mother's age & 39.10 & 4.86 & 40.95 & 4.34 \\
\hline Mother's education: No schooling & 0.48 & 0.50 & 0.36 & 0.48 \\
\hline Mother's education: primary school & 0.42 & 0.49 & 0.50 & 0.50 \\
\hline Mother's education: Jun. high school & 0.03 & 0.18 & 0.05 & 0.21 \\
\hline Mother's education: high school & 0.06 & 0.24 & 0.10 & 0.29 \\
\hline Mother's mother tongue: Kurdish & 0.74 & 0.44 & 0.77 & 0.42 \\
\hline Mother's mother tongue: Kurdish & 0.22 & 0.42 & 0.19 & 0.39 \\
\hline Mother's mother tongue: Arabic and other & 0.04 & 0.19 & 0.04 & 0.19 \\
\hline Mother's education: No schooling & 0.16 & 0.37 & 0.09 & 0.29 \\
\hline Father's education: primary school & 0.56 & 0.50 & 0.56 & 0.50 \\
\hline Father's education: Jun. high school & 0.10 & 0.30 & 0.11 & 0.32 \\
\hline Father's education: high school & 0.17 & 0.38 & 0.24 & 0.43 \\
\hline Father's mother tongue: Turkish & 0.74 & 0.44 & 0.76 & 0.42 \\
\hline Father's mother tongue: Kurdish & 0.22 & 0.42 & 0.20 & 0.40 \\
\hline Father's mother tongue: Arabic and other & 0.04 & 0.20 & 0.04 & 0.19 \\
\hline Female & 0.49 & 0.50 & 0.43 & 0.50 \\
\hline Age & 14.71 & 1.99 & 17.01 & 2.21 \\
\hline Birth order: 1 & 0.37 & 0.48 & 0.46 & 0.50 \\
\hline Birth order: $2-3$ & 0.49 & 0.50 & 0.46 & 0.50 \\
\hline Birth order: $4-6$ & 0.12 & 0.33 & 0.07 & 0.25 \\
\hline Birth order: more than 6 & 0.01 & 0.12 & 0.01 & 0.07 \\
\hline Number of siblings: 0 & 0.19 & 0.39 & 0.24 & 0.43 \\
\hline Number of siblings: $3-5$ & 0.53 & 0.50 & 0.55 & 0.50 \\
\hline Number of siblings: $>6$ & 0.28 & 0.45 & 0.21 & 0.40 \\
\hline Poorest & 0.21 & 0.41 & 0.12 & 0.33 \\
\hline Poorer & 0.19 & 0.40 & 0.19 & 0.39 \\
\hline Middle & 0.22 & 0.42 & 0.22 & 0.41 \\
\hline Richer & 0.20 & 0.40 & 0.24 & 0.43 \\
\hline Richest & 0.17 & 0.38 & 0.22 & 0.42 \\
\hline Urban & 0.67 & 0.47 & 0.74 & 0.44 \\
\hline$N$ & 3471 & & 3839 & \\
\hline
\end{tabular}

Source: Authors' calculations based on TDHS data, 1998 and 2003 rounds 
the samples to children in ages 12-18 and living in the same household as the mother. The reasons for this decision are twofold. First, children are enrolled in primary school until age 11, and children younger than 12 are not supposed to graduate from primary school. Moreover, children who are 12 or older have not been subject to the change in compulsory schooling law in 1997. Second, children tend to leave their parental household after age 18 at a higher speed, for reasons such as marriage and migration to another province for college education. Therefore, we exclude children who are older than 18 in order to avoid a sample selection problem.

As can be seen in column $1,33 \%$ of children drop out after compulsory primary school. The mean of the traditional view indicator is 0.29 . This means that $29 \%$ of children in our sample have mothers who indicate that it is better to educate sons.

We use TDHS 1998 and not TDHS 2003 in the first set of regression analyses, because children aged 12-18 in the 2003 data were born during 1985-1991 and some cohorts in this sample were affected by the change in compulsory schooling law while others were not. In our first set of analyses, our goal is to isolate the effect of mother's views on gender roles and not to confound the results with the effects of the reform.

Column 2 presents descriptive statistics for the sample used in our second set of analyses, where we study the effects of change in compulsory schooling law on the gender gap in education. This sample consists of children who completed primary school (5 years of schooling), were born during 1983-1990 and live in the same household as the mother. This sample is constructed to provide a balanced number of cohorts in the pre- and postreform periods. We observe that, among the children who completed primary school, $17 \%$ drop out after primary school and $18 \%$ of children drop out after junior high school (8 years of schooling) in this sample.

Figure 1 shows, using data from the 1998 TDHS, the share of children enrolled in school by age and gender of the child and by mother's traditional view indicator. In the figure, dark colored lines represent female children; light colored ones represent male children. It can be observed that maternal attitude on gender role is highly correlated with the gender gap in educational attainment. The sharp decline in the enrolment rates of girls whose mothers have a traditional view on gender roles is clearly visible in the figure. On

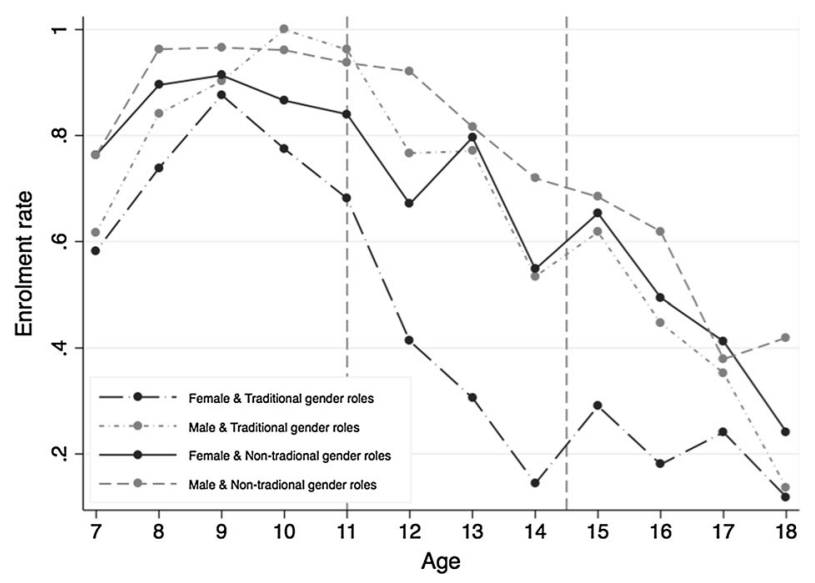

Fig. 1 Enrollment rate by age and gender of the child and by the mother's traditional view indicator (TDHS 1998) 
average, dropout rates of girls whose mothers have a traditional view on gender roles are much higher than dropout rates of boys at the same age. Moreover, girls whose mothers hold a non-traditional view on gender roles have almost as much chance as boys to stay in school. For the school enrolment of boys, mothers' views on gender roles appear not to matter much. Last but not least, we observe that for female children whose mothers hold a traditional view the educational disadvantage increases substantially after the completion of compulsory education, i.e. for those who were 12 or older in 1998.

\section{Results}

\subsection{Mother's View on Gender Roles and the Educational Attainment of Children}

Table 2 presents the estimates of Eq. (1). In column 1, the dependent variable is equal to 1 if the individual dropped out without completing 5 years of primary education (which was the compulsory level of schooling prior to the 1997 reform), 0 otherwise. In column 2, it is equal to 1 if the individual dropped out after completing primary school, 0 otherwise. In column 3 , it is equal to 1 if the individual dropped out after completing junior high school (8 years of schooling), 0 otherwise. We have a large set of control variables. In all three columns, we present estimates with and without additional controls, but in the text we explain the estimates that are obtained with controls.

Column 1 shows that for boys the mother's view on gender roles does not affect the probability of completing primary school (i.e., the coefficient estimate of "Traditional" is economically and statistically small). Yet, being female increases the likelihood of being a primary school dropout by $2.8 \%$ points. For girls whose mothers hold a traditional view on gender roles, the probability of completing compulsory schooling level is lower by $9.5 \%$ points $(2.8+6.7)$. In column 2 , we investigate the impact of having a mother with traditional view regarding gender roles on dropping out, conditional on completing the primary school. Once again, for boys, having a mother with a traditional view does not have an impact on the likelihood of dropping out. On the other hand, for girls, whose mothers hold a non-traditional view on gender roles, the probability to continue education after satisfying the legal requirement is on average $12.8 \%$ points lower than it is for boys whose mothers hold a non-traditional view. For girls whose mothers have a traditional view, the chance to stay in school after primary school is on average $30.1 \%$ points $(12.8+17.3)$ lower than it is for boys whose mothers hold a traditional view. To summarize, we find that for the birth cohorts that were not subject to the 1997 reform, the daughters of women with a traditional view are more likely to drop out during and after primary school compared to the sons of women with the same view.

In column 3, we examine the impact of maternal attitudes towards gender roles on dropping out after junior high school. We observe that neither being female nor having a mother who holds a traditional view on gender roles has a statistically significant effect on dropout rates conditional on completing junior high school. This means that among children who have already completed junior high school, no difference in dropout rates is observed according to gender or mother's traditional view.

As a result, our first hypothesis is verified in the sense that the dropout rates during and after primary school are higher for girls, compared to the rates for boys. Our second hypothesis is also verified since daughters of women with a traditional view achieve lower 
Table 2 Mother's view on gender roles and children's educational attainment (TDHS 1998)

\begin{tabular}{|c|c|c|c|c|c|c|}
\hline \multirow{2}{*}{$\begin{array}{l}\text { Dependent variable } \\
\text { Mean values of the } \\
\text { dependent variables }\end{array}$} & \multicolumn{2}{|l|}{ (1) } & \multicolumn{2}{|l|}{ (2) } & \multicolumn{2}{|l|}{ (3) } \\
\hline & $\begin{array}{l}\text { Dropout } \\
\text { during } \\
\text { primary } \\
\text { school } \\
{[0.09]}\end{array}$ & $\begin{array}{l}\text { Dropout } \\
\text { during } \\
\text { primary } \\
\text { school }\end{array}$ & $\begin{array}{l}\text { Dropout } \\
\text { after } \\
\text { primary } \\
\text { school } \\
{[0.33]}\end{array}$ & $\begin{array}{l}\text { Dropout } \\
\text { after } \\
\text { primary } \\
\text { school }\end{array}$ & $\begin{array}{l}\text { Dropout } \\
\text { after junior } \\
\text { high school } \\
{[0.13]}\end{array}$ & $\begin{array}{l}\text { Dropout } \\
\text { after junior } \\
\text { high school }\end{array}$ \\
\hline $\begin{array}{l}\text { Traditional } \\
\text { (indicator) }\end{array}$ & $\begin{array}{l}0.026 \\
(1.67)\end{array}$ & $\begin{array}{l}-0.018 \\
(1.20)\end{array}$ & $\begin{array}{l}0.175 * * * \\
(6.37)\end{array}$ & $\begin{array}{l}0.025 \\
(0.98)\end{array}$ & $\begin{array}{l}0.111 * * \\
(2.97)\end{array}$ & $\begin{array}{l}0.062 \\
(1.65)\end{array}$ \\
\hline Traditional $\times$ female & $\begin{array}{l}0.083 * * * \\
(3.37)\end{array}$ & $\begin{array}{l}0.067 * * \\
(2.95)\end{array}$ & $\begin{array}{l}0.189 * * * \\
(4.82)\end{array}$ & $\begin{array}{l}0.173 * * * \\
(4.88)\end{array}$ & $\begin{array}{l}-0.007 \\
(0.13)\end{array}$ & $\begin{array}{l}-0.011 \\
(0.20)\end{array}$ \\
\hline Female & $\begin{array}{l}0.022 * \\
(1.98)\end{array}$ & $\begin{array}{l}0.028 * * \\
(2.60)\end{array}$ & $\begin{array}{l}0.122 * * * \\
(6.40)\end{array}$ & $\begin{array}{l}0.128 * * * \\
(7.90)\end{array}$ & $\begin{array}{l}-0.028 \\
(1.41)\end{array}$ & $\begin{array}{l}-0.007 \\
(0.36)\end{array}$ \\
\hline Age & & $\begin{array}{l}-0.171 * * * \\
(4.49)\end{array}$ & & $\begin{array}{l}0.197 * * * \\
(3.32)\end{array}$ & & $\begin{array}{l}-0.036 \\
(0.34)\end{array}$ \\
\hline Age-squared/100 & & $\begin{array}{l}0.523 * * * \\
(4.20)\end{array}$ & & $\begin{array}{l}-0.584 * * \\
(2.94)\end{array}$ & & $\begin{array}{l}0.204 \\
(0.61)\end{array}$ \\
\hline Birth order: $2-3$ & & $\begin{array}{l}0.009 \\
(0.93)\end{array}$ & & $\begin{array}{l}0.032 * \\
(2.03)\end{array}$ & & $\begin{array}{l}0.019 \\
(1.01)\end{array}$ \\
\hline Birth order: 4-6 & & $\begin{array}{l}0.037 \\
(1.67)\end{array}$ & & $\begin{array}{l}-0.002 \\
(0.07)\end{array}$ & & $\begin{array}{l}0.015 \\
(0.33)\end{array}$ \\
\hline $\begin{array}{l}\text { Birth order: more } \\
\text { than } 6\end{array}$ & & $\begin{array}{l}0.051 \\
(0.75)\end{array}$ & & $\begin{array}{l}-0.110 \\
(1.50)\end{array}$ & & $\begin{array}{l}-0.055 \\
(0.32)\end{array}$ \\
\hline South & & $\begin{array}{l}-0.011 \\
(0.82)\end{array}$ & & $\begin{array}{l}-0.053 * \\
(2.15)\end{array}$ & & $\begin{array}{l}-0.070 * \\
(2.51)\end{array}$ \\
\hline Center & & $\begin{array}{l}-0.010 \\
(0.85)\end{array}$ & & $\begin{array}{l}-0.054 * \\
(2.24)\end{array}$ & & $\begin{array}{l}-0.013 \\
(0.45)\end{array}$ \\
\hline North & & $\begin{array}{l}-0.009 \\
(0.77)\end{array}$ & & $\begin{array}{l}-0.073 * * \\
(2.85)\end{array}$ & & $\begin{array}{l}-0.066^{*} \\
(2.37)\end{array}$ \\
\hline East & & $\begin{array}{l}0.056^{* *} \\
(3.02)\end{array}$ & & $\begin{array}{l}-0.083^{* * *} \\
(2.87)\end{array}$ & & $\begin{array}{l}-0.039 \\
(1.17)\end{array}$ \\
\hline Poorer & & $\begin{array}{l}-0.083 * * * \\
(3.81)\end{array}$ & & $\begin{array}{l}-0.107 * * * \\
(3.39)\end{array}$ & & $\begin{array}{l}0.048 \\
(0.83)\end{array}$ \\
\hline Middle & & $\begin{array}{l}-0.114 * * * \\
(5.26)\end{array}$ & & $\begin{array}{l}-0.251 * * * \\
(7.85)\end{array}$ & & $\begin{array}{l}-0.010 \\
(0.20)\end{array}$ \\
\hline Richer & & $\begin{array}{l}-0.117 * * * \\
(5.25)\end{array}$ & & $\begin{array}{l}-0.312 * * * \\
(8.82)\end{array}$ & & $\begin{array}{l}-0.036 \\
(0.68)\end{array}$ \\
\hline Richest & & $\begin{array}{l}-0.111^{* * * *} \\
(4.50)\end{array}$ & & $\begin{array}{l}-0.355^{* * *} \\
(9.58)\end{array}$ & & $\begin{array}{l}-0.062 \\
(1.17)\end{array}$ \\
\hline $\begin{array}{l}\text { Mother's education: } \\
\text { primary school }\end{array}$ & & $\begin{array}{l}-0.027 * \\
(2.28)\end{array}$ & & $\begin{array}{l}-0.027 \\
(1.30)\end{array}$ & & $\begin{array}{l}-0.047 \\
(1.74)\end{array}$ \\
\hline $\begin{array}{l}\text { Mother's education: } \\
\text { junior high school }\end{array}$ & & $\begin{array}{l}-0.029 \\
(1.92)\end{array}$ & & $\begin{array}{l}-0.082 * \\
(2.54)\end{array}$ & & $\begin{array}{l}-0.021 \\
(0.48)\end{array}$ \\
\hline $\begin{array}{l}\text { Mother's education: } \\
\text { high school }\end{array}$ & & $\begin{array}{l}-0.012 \\
(0.75)\end{array}$ & & $\begin{array}{l}0.004 \\
(0.14)\end{array}$ & & $\begin{array}{l}-0.043 \\
(1.33)\end{array}$ \\
\hline
\end{tabular}


Table 2 continued

\begin{tabular}{|c|c|c|c|c|c|c|}
\hline \multirow{2}{*}{$\begin{array}{l}\text { Dependent } \\
\text { variable } \\
\text { Mean values of } \\
\text { the dependent } \\
\text { variables }\end{array}$} & \multicolumn{2}{|l|}{ (1) } & \multicolumn{2}{|l|}{ (2) } & \multicolumn{2}{|l|}{ (3) } \\
\hline & $\begin{array}{l}\text { Dropout } \\
\text { during } \\
\text { primary } \\
\text { school } \\
{[0.09]}\end{array}$ & $\begin{array}{l}\text { Dropout } \\
\text { during } \\
\text { primary } \\
\text { school }\end{array}$ & $\begin{array}{l}\text { Dropout } \\
\text { after } \\
\text { primary } \\
\text { school } \\
{[0.33]}\end{array}$ & $\begin{array}{l}\text { Dropout } \\
\text { after } \\
\text { primary } \\
\text { school }\end{array}$ & $\begin{array}{l}\text { Dropout } \\
\text { after junior } \\
\text { high school } \\
{[0.13]}\end{array}$ & $\begin{array}{l}\text { Dropout } \\
\text { after junior } \\
\text { high school }\end{array}$ \\
\hline Mother's age & & $\begin{array}{l}0.002 \\
(0.09)\end{array}$ & & $\begin{array}{l}-0.028 \\
(1.16)\end{array}$ & & $\begin{array}{l}-0.094^{*} \\
(2.45)\end{array}$ \\
\hline $\begin{array}{l}\text { Mother's age- } \\
\text { squared/100 }\end{array}$ & & $\begin{array}{l}-0.005 \\
(0.24)\end{array}$ & & $\begin{array}{l}0.031 \\
(1.04)\end{array}$ & & $\begin{array}{l}0.114 * \\
(2.41)\end{array}$ \\
\hline $\begin{array}{l}\text { Father's } \\
\text { education: } \\
\text { primary school }\end{array}$ & & $\begin{array}{l}-0.051^{*} \\
(2.37)\end{array}$ & & $\begin{array}{l}-0.091 * * \\
(3.00)\end{array}$ & & $\begin{array}{l}-0.030 \\
(0.62)\end{array}$ \\
\hline $\begin{array}{l}\text { Father's } \\
\text { education: } \\
\text { junior high } \\
\text { school }\end{array}$ & & $\begin{array}{l}-0.082 * * \\
(3.20)\end{array}$ & & $\begin{array}{l}-0.209 * * * \\
(5.76)\end{array}$ & & $\begin{array}{l}-0.102 \\
(1.95)\end{array}$ \\
\hline $\begin{array}{l}\text { Father's } \\
\text { education: } \\
\text { high school }\end{array}$ & & $\begin{array}{l}-0.078 * * \\
(3.28)\end{array}$ & & $\begin{array}{l}-0.231 \text { *** } \\
(6.73)\end{array}$ & & $\begin{array}{l}-0.081 \\
(1.59)\end{array}$ \\
\hline $\begin{array}{l}\text { Mother's mother } \\
\text { tongue: } \\
\text { Kurdish }\end{array}$ & & $\begin{array}{l}0.084 * \\
(2.10)\end{array}$ & & $\begin{array}{l}0.009 \\
(0.15)\end{array}$ & & $\begin{array}{l}-0.108^{*} \\
(2.28)\end{array}$ \\
\hline $\begin{array}{l}\text { Mother's mother } \\
\text { tongue: Arabic } \\
\text { and other }\end{array}$ & & $\begin{array}{l}0.050 \\
(0.61)\end{array}$ & & $\begin{array}{l}0.019 \\
(0.22)\end{array}$ & & $\begin{array}{l}-0.089 \\
(1.77)\end{array}$ \\
\hline $\begin{array}{l}\text { Father's mother } \\
\text { tongue: } \\
\text { Kurdish }\end{array}$ & & $\begin{array}{l}0.052 \\
(1.34)\end{array}$ & & $\begin{array}{l}0.022 \\
(0.39)\end{array}$ & & $\begin{array}{l}0.102 * \\
(2.04)\end{array}$ \\
\hline $\begin{array}{l}\text { Father's mother } \\
\text { tongue: Arabic } \\
\text { and other }\end{array}$ & & $\begin{array}{l}0.007 \\
(0.09)\end{array}$ & & $\begin{array}{l}0.073 \\
(0.84)\end{array}$ & & $\begin{array}{l}0.044 \\
(0.80)\end{array}$ \\
\hline Urban & & $\begin{array}{l}0.014 \\
(0.94)\end{array}$ & & $\begin{array}{l}-0.026 \\
(1.19)\end{array}$ & & $\begin{array}{l}-0.046 \\
(1.50)\end{array}$ \\
\hline $\begin{array}{l}\text { Number of } \\
\text { siblings: } 3-5\end{array}$ & & $\begin{array}{l}-0.016 \\
(1.71)\end{array}$ & & $\begin{array}{l}0.089^{* * * *} \\
(4.67)\end{array}$ & & $\begin{array}{l}0.011 \\
(0.54)\end{array}$ \\
\hline $\begin{array}{l}\text { Number of } \\
\text { siblings: }>6\end{array}$ & & $\begin{array}{l}-0.001 \\
(0.03)\end{array}$ & & $\begin{array}{l}0.182 * * * \\
(5.57)\end{array}$ & & $\begin{array}{l}0.117 * \\
(2.44)\end{array}$ \\
\hline Constant & $\begin{array}{l}0.064 * * * \\
(8.25)\end{array}$ & $\begin{array}{l}1.544 * * * \\
(3.66)\end{array}$ & $\begin{array}{l}0.196 * * * \\
(15.19)\end{array}$ & $\begin{array}{l}-0.485 \\
(0.80)\end{array}$ & $\begin{array}{l}0.124 * * * \\
(8.99)\end{array}$ & $\begin{array}{l}2.234 \\
(1.95)\end{array}$ \\
\hline$N$ & 3471 & 3471 & 3146 & 3146 & 1324 & 1324 \\
\hline Adjusted $R^{2}$ & 0.020 & 0.202 & 0.099 & 0.308 & 0.016 & 0.090 \\
\hline
\end{tabular}

OLS regressions of Eq. (1). Absolute $t$-statistics are in parentheses and standard errors are clustered at the mother level

$* p<0.05$; ** $p<0.01$; *** $p<0.001$ 


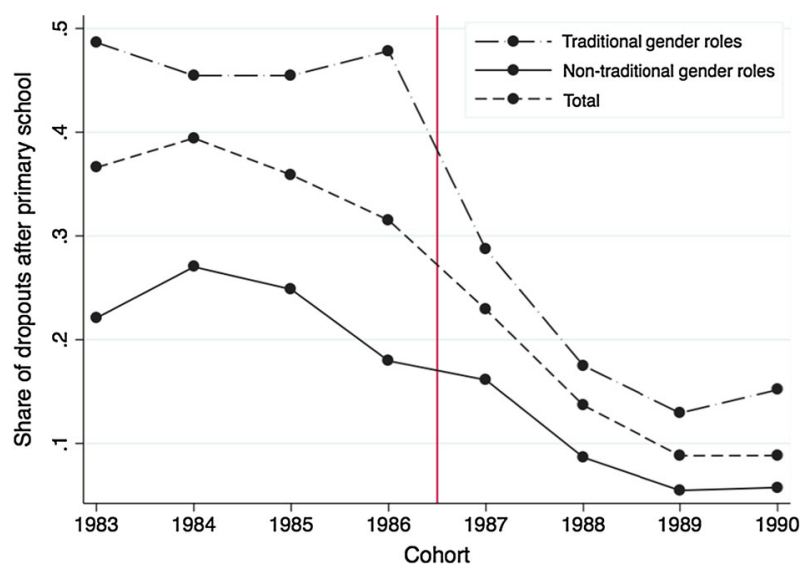

Fig. 2 Dropout rate after primary school by birth cohort and mother's view on gender roles (TDHS 2003)

educational attainment compared to the sons of women with a similar view. When mothers have a non-traditional view, girls are still at a disadvantage against boys since they have a higher probability to drop out during and after primary school. However, the disadvantage of girls against boys is much larger when mothers have a traditional view. The effect persists even after controlling for a large number of factors.

\subsection{The Interaction of Compulsory Schooling with Mother's View on Gender Roles}

In the second set of analyses, we investigate the impact of the extension of compulsory schooling on the adverse effects of traditional views on gender roles. We exploit an education reform and explore whether the reform helped mitigate the disadvantage faced by the girls whose mothers favor the education of the male children over the female children.

Figure 2 shows dropout rates conditional on completing primary school by birth cohort and mother's view on gender roles using TDHS 2003 data. In this part of our analysis we use the 2003 data since it includes cohorts that have been affected by the education reform as well as cohorts that have not been affected by the education reform. ${ }^{4}$ The dashed line at the top shows dropout rates of children whose mothers favor the education of the male child over the female child. The solid line at the bottom shows dropout rates of children whose mothers have a non-traditional view, and the line in the middle shows rates for the full sample. It can be seen from Fig. 2 that dropout rates of the "post-reform" cohorts are lower by about 25-30\% points than dropout rates of the pre-reform cohorts. It can also be observed that the compulsory schooling education reform considerably narrowed the education gap between children whose mothers hold a traditional view and whose mothers hold a non-traditional view.

\footnotetext{
${ }^{4}$ Because of a potential selection problem, we do not use the 2008 TDHS data, but we use only TDHS 2003 data. In 2008, the students who were not subject to the reform are 21 or older. Students who have mothers with a traditional view on gender roles are more likely to leave the household at an early age; therefore the pre-reform students that we would observe in the 2008 data are probably a selected sample.
} 


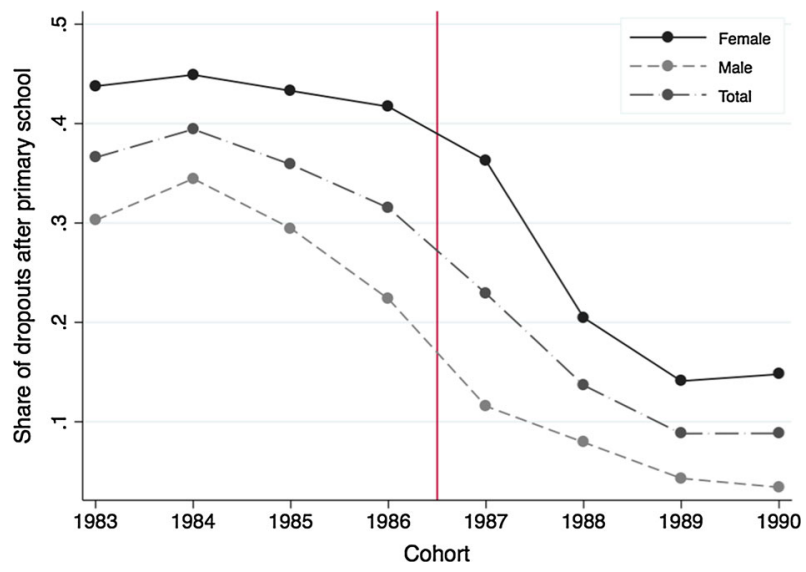

Fig. 3 Dropout rate after primary school by birth cohort and gender (TDHS 2003)

Figure 3 shows dropout rates conditional on completing primary school by cohort and gender. The solid line at the top represents female children, and the dashed line at the bottom represents male children. We observe that dropout rates are considerably lower for both male and female children for cohorts that were affected by the education reform, but unfortunately the gender gap in dropout rates remained persistent.

Figure 4 depicts dropout rates after primary school by gender and maternal attitudes on gender roles. This figure shows that dropout rates of male and female children of mothers with a traditional view on gender roles follow a similar pre- and post-reform trend (darker dashed line versus lighter dashed line). In other words, although the dropout rates fell substantially after the implementation of compulsory education reform, among children whose mothers have a traditional view the gender gap in the dropout rates remained persistent. Interestingly, the gap in dropout rates between female and male children of mothers with a non-traditional view exhibits an increasing trend prior to the reform and appears to have narrowed in the post reform period. It is also worth noting that in the postreform cohorts boys whose mothers hold a traditional view appear to stay in school as long as boys whose mothers hold a non-traditional view.

The graphical analysis suggests that although there has been a decrease in dropout rates, the gender gap remained persistent in the post-reform cohorts. Next, we estimate Eq. (2) in order to test our third hypothesis and analyze whether the reform reduced the adverse effects of traditional views on gender gap in education. Table 3 presents these results. Once again, in the text we describe the results with a full set of controls.

The sample that is used for regressions shown in column 1 of Table 3 includes 1983-1990 birth cohorts (four cohorts that are affected by the reform and four cohorts that are not affected by the reform). The estimates show that the reform reduced the probability to dropout after primary school by 14.9 (33.5) \% points for boys with mothers holding traditional (non-traditional) views. ${ }^{5}$ Since the coefficient estimates of the interaction terms

\footnotetext{
5 For children of mothers with non-traditional views, "Traditional" is 0 . If the child is male, "Female" is 0. Hence the coefficient on "Post reform" $(-14.9)$ implies that the reform increased the probability to stay in school by $14.9 \%$ points for boys whose mother have a non-traditional view. For mothers with a traditional view, "Traditional" is 1 and the coefficient on "Post reform" (-14.9) plus the coefficient on "Post reform*Traditional" (-18.6) equals $33.5 \%$ points of increased probability to stay in school for boys whose mothers have a traditional view. This corresponds to $\beta_{4}+\beta_{5}$ in Eq. 2.
} 


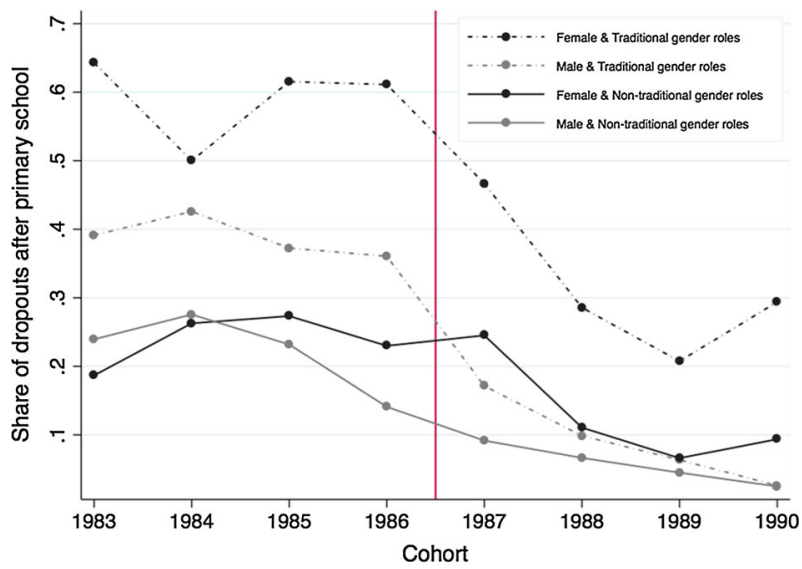

Fig. 4 Dropout rate after primary school by birth cohort, gender and mother's view on gender roles (TDHS 2003)

"Post reform $\times$ Female" and "Post reform $\times$ Traditional $\times$ Female" are economically and statistically insignificant, we conclude that the reform did not have any differential effects for girls (independent of the views of their mothers). In other words, for girls with mothers holding traditional (non-traditional) views, the reform reduced the probability to dropout after primary school also by 14.9 (33.5) \% points. Therefore, the gender gap is not eliminated by the reform.

In column 1 of Table 3, the interaction term "Post reform $\times$ Traditional" is statistically significant with a point estimate of -0.186 . This means that the reform decreased the dropout rates by $18.6 \%$ points more for boys whose mothers have a traditional view than for boys whose mothers have a non-traditional view. Hence the reform did reduce the education gap between boys with traditional mothers and boys with non-traditional mothers. Since the estimate of "Post reform $\times$ Traditional $\times$ Female" is very small in magnitude and statistically insignificant, $18.6 \%$ points reduction is also the coefficient estimate for girls.

Although the reform reduced the education gap between children of traditional mothers and non-traditional mothers, it had a similar effect on the dropout probabilities of boys and girls. We would instead expect it to have a larger effect on the dropout probability of girls, compared to boys. To summarize our main result, we say that the reform failed to eliminate the gender gap against girls although it helped to reduce school dropout rates in general.

For a robustness check of our results, we repeat the analyses with a restricted sample, a sample that includes only the 1984-1989 birth cohorts (three pre-reform and three postreform cohorts). Column 2 shows the results, once again, without and with controls. Evidently, the main findings are robust to the change in the sample.

Hence, we fail to verify our third hypothesis since we find that the reform had a similar effect on boys and girls whose mothers hold a traditional view (similar results are found for those whose mothers hold a non-traditional view). Since girls whose mothers hold a traditional view are particularly disadvantaged, for the gender gap to be reduced we would expect the reform to have a larger effect on this group of children. We fail to detect such an effect. 
Table 3 Mother's view on gender roles and children's dropout probability (TDHS 2003)

\begin{tabular}{|c|c|c|c|c|}
\hline \multirow{3}{*}{$\begin{array}{l}\text { Dependent variable: dropout after primary school } \\
\text { Samples } \\
\text { Mean values of the dependent variables }\end{array}$} & \multicolumn{2}{|l|}{ (1) } & \multicolumn{2}{|l|}{ (2) } \\
\hline & \multicolumn{2}{|c|}{ Born in $1983-1990$} & \multicolumn{2}{|c|}{ Born in 1984-1989 } \\
\hline & {$[0.17]$} & & {$[0.17]$} & \\
\hline Traditional (indicator) & $\begin{array}{l}0.183^{* * * *} \\
(4.53)\end{array}$ & $\begin{array}{l}0.155^{* * *} \\
(4.31)\end{array}$ & $\begin{array}{l}0.195^{* * * *} \\
(4.31)\end{array}$ & $\begin{array}{l}0.164 * * * \\
(4.05)\end{array}$ \\
\hline Traditional $\times$ female & $\begin{array}{l}0.169^{* *} \\
(2.71)\end{array}$ & $\begin{array}{l}0.116^{*} \\
(2.02)\end{array}$ & $\begin{array}{l}0.138 * \\
(1.97)\end{array}$ & $\begin{array}{l}0.079 \\
(1.22)\end{array}$ \\
\hline Female & $\begin{array}{l}0.029 \\
(1.15)\end{array}$ & $\begin{array}{l}0.070 * * \\
(3.14)\end{array}$ & $\begin{array}{l}0.050 \\
(1.84)\end{array}$ & $\begin{array}{l}0.088^{* * * *} \\
(3.60)\end{array}$ \\
\hline Post reform & $\begin{array}{l}-0.155^{* * *} \\
(9.23)\end{array}$ & $\begin{array}{l}-0.149^{* * * *} \\
(9.14)\end{array}$ & $\begin{array}{l}-0.133^{* * * *} \\
(7.22)\end{array}$ & $\begin{array}{l}-0.119 * * * \\
(6.58)\end{array}$ \\
\hline Post reform $\times$ female & $\begin{array}{l}0.038 \\
(1.33)\end{array}$ & $\begin{array}{l}0.017 \\
(0.65)\end{array}$ & $\begin{array}{l}0.017 \\
(0.55)\end{array}$ & $\begin{array}{l}-0.005 \\
(0.19)\end{array}$ \\
\hline Post reform $\times$ traditional & $\begin{array}{l}-0.152 * * * \\
(3.57)\end{array}$ & $\begin{array}{l}-0.186^{* * *} \\
(4.76)\end{array}$ & $\begin{array}{l}-0.153^{* *} \\
(3.13)\end{array}$ & $\begin{array}{l}-0.181 * * * \\
(4.00)\end{array}$ \\
\hline Post reform $\times$ traditional $\times$ female & $\begin{array}{l}-0.006 \\
(0.08)\end{array}$ & $\begin{array}{l}0.024 \\
(0.35)\end{array}$ & $\begin{array}{l}0.003 \\
(0.04)\end{array}$ & $\begin{array}{l}0.030 \\
(0.38)\end{array}$ \\
\hline Birth order: $2-3$ & & $\begin{array}{l}0.006 \\
(0.54)\end{array}$ & & $\begin{array}{l}0.004 \\
(0.27)\end{array}$ \\
\hline Birth order: $4-6$ & & $\begin{array}{l}-0.054 \\
(1.77)\end{array}$ & & $\begin{array}{l}-0.081^{*} \\
(2.28)\end{array}$ \\
\hline Birth order: more than 6 & & $\begin{array}{l}-0.043 \\
(0.43)\end{array}$ & & $\begin{array}{l}-0.095 \\
(0.69)\end{array}$ \\
\hline South & & $\begin{array}{l}-0.071 * * * \\
(3.60)\end{array}$ & & $\begin{array}{l}-0.064 * * \\
(2.71)\end{array}$ \\
\hline Center & & $\begin{array}{l}-0.081^{* * *} \\
(4.54)\end{array}$ & & $\begin{array}{l}-0.076^{* * *} \\
(3.61)\end{array}$ \\
\hline North & & $\begin{array}{l}-0.070^{* * *} \\
(3.66)\end{array}$ & & $\begin{array}{l}-0.067 * * \\
(2.85)\end{array}$ \\
\hline East & & $\begin{array}{l}-0.079 * * * \\
(3.79)\end{array}$ & & $\begin{array}{l}-0.095 * * * \\
(3.85)\end{array}$ \\
\hline Poorer & & $\begin{array}{l}-0.046 \\
(1.65)\end{array}$ & & $\begin{array}{l}-0.049 \\
(1.46)\end{array}$ \\
\hline Middle & & $\begin{array}{l}-0.121^{* * * *} \\
(4.48)\end{array}$ & & $\begin{array}{l}-0.114 * * * \\
(3.58)\end{array}$ \\
\hline Richer & & $\begin{array}{l}-0.125^{* * * *} \\
(4.47)\end{array}$ & & $\begin{array}{l}-0.111^{* * * *} \\
(3.34)\end{array}$ \\
\hline Richest & & $\begin{array}{l}-0.179^{* * *} \\
(6.51)\end{array}$ & & $\begin{array}{l}-0.171 \text { *** } \\
(5.29)\end{array}$ \\
\hline Mother's education: primary school & & $\begin{array}{l}-0.018 \\
(1.03)\end{array}$ & & $\begin{array}{l}-0.019 \\
(0.89)\end{array}$ \\
\hline Mother's education: Jun. high school & & $\begin{array}{l}-0.039 \\
(1.63)\end{array}$ & & $\begin{array}{l}-0.038 \\
(1.21)\end{array}$ \\
\hline
\end{tabular}


Table 3 continued

\begin{tabular}{|c|c|c|c|c|}
\hline \multirow{3}{*}{$\begin{array}{l}\text { Dependent variable: dropout after primary school } \\
\text { Samples } \\
\text { Mean values of the dependent variables }\end{array}$} & \multicolumn{2}{|l|}{$(1)$} & \multicolumn{2}{|l|}{ (2) } \\
\hline & \multicolumn{2}{|c|}{ Born in 1983-1990 } & \multicolumn{2}{|c|}{ Born in $1984-1989$} \\
\hline & {$[0.17]$} & & {$[0.17]$} & \\
\hline \multirow[t]{2}{*}{ Mother's education: high school } & & -0.011 & & -0.009 \\
\hline & & $(0.56)$ & & $(0.36)$ \\
\hline \multirow[t]{2}{*}{ Mother's age } & & $0.049 *$ & & $0.059 *$ \\
\hline & & $(2.37)$ & & $(2.07)$ \\
\hline \multirow[t]{2}{*}{ Mother's age-squared/100 } & & $-0.061 *$ & & $-0.072 *$ \\
\hline & & $(2.38)$ & & $(2.10)$ \\
\hline \multirow[t]{2}{*}{ Father's education: primary school } & & -0.026 & & -0.027 \\
\hline & & $(0.85)$ & & $(0.73)$ \\
\hline \multirow[t]{2}{*}{ Father's education: Jun. high school } & & $-0.082 *$ & & $-0.086^{*}$ \\
\hline & & $(2.50)$ & & $(2.19)$ \\
\hline \multirow[t]{2}{*}{ Father's education: high school } & & $-0.102 * *$ & & $-0.113 * *$ \\
\hline & & $(3.24)$ & & $(2.94)$ \\
\hline \multirow[t]{2}{*}{ Mother's mother tongue: Kurdish } & & -0.029 & & -0.051 \\
\hline & & $(0.88)$ & & $(1.21)$ \\
\hline \multirow[t]{2}{*}{ Mother's mother tongue: Arabic and other } & & -0.007 & & -0.037 \\
\hline & & $(0.15)$ & & $(0.71)$ \\
\hline \multirow[t]{2}{*}{ Father's mother tongue: Kurdish } & & $0.084 * *$ & & $0.100^{*}$ \\
\hline & & $(2.76)$ & & $(2.52)$ \\
\hline \multirow[t]{2}{*}{ Father's mother tongue: Arabic and other } & & 0.054 & & 0.040 \\
\hline & & $(1.12)$ & & $(0.71)$ \\
\hline \multirow[t]{2}{*}{ Urban } & & $-0.040 *$ & & $-0.047 *$ \\
\hline & & $(2.39)$ & & $(2.41)$ \\
\hline \multirow[t]{2}{*}{ Number of siblings: $3-5$} & & $0.045 * * *$ & & $0.060 * * *$ \\
\hline & & $(3.47)$ & & $(4.01)$ \\
\hline \multirow[t]{2}{*}{ Number of siblings: $>6$} & & $0.188 * * *$ & & $0.225 * * *$ \\
\hline & & $(6.92)$ & & $(7.10)$ \\
\hline \multirow[t]{2}{*}{ Constant } & $0.211 * * *$ & -0.600 & $0.201 * * *$ & -0.804 \\
\hline & $(13.11)$ & $(1.42)$ & $(11.56)$ & $(1.38)$ \\
\hline$N$ & 3839 & 3839 & 2889 & 2889 \\
\hline Adjusted $R^{2}$ & 0.100 & 0.229 & 0.089 & 0.218 \\
\hline
\end{tabular}

OLS regressions. Absolute $t$-statistics are in parentheses and standard errors are clustered at the mother level. The only change caused by an inclusion of age and age-squared as controls is the reduction of the absolute value of the estimate of "Traditional", which results from the high explanatory power of the 2nd order polynomial of age in explaining the trend before and after reform

$* p<0.05$;** $p<0.01$; *** $p<0.001$

The two studies in the literature that are the most closely related to our work disagree in their results on how the education gender gap was affected by the reform. Kirdar et al. (2013) find that the reform did not reduce the gender gap in educational attainment. Gulesci and Myersson (2013), on the other hand, find that the reform reduced the gender 
gap. Both of these two studies use the TDHS data, as we do. The former study looks at grade completion rates and finds no evidence for a narrowing gender gap despite higher post-reform rates for both sexes. The latter study finds that women's average years of schooling increased by 1 year whereas men's schooling remained the same, thereby reducing the education gender gap. Our study brings a new perspective to the literature by questioning the gender gap across the children of mothers with different views on gender roles.

\section{Mother's Views on Gender Roles: A Discussion of Measurement Issues}

In our baseline results, we defined the variable that measures the view on gender roles as a dummy indicator variable based on whether a mother agreed with the statement that it is better for a male child to have education than a female child.

As described in the data section, in the TDHS, the respondents are asked several questions about gender inequality. They are asked whether they agree with the following statements: (1) "Men are wiser than women"; (2) "A man can beat his wife"; (3) "A woman should not argue with her husband"; (4) "It is better for a male child to have education than a female child"; (5) "Important decisions in the household should be made by men". The responses are coded as agree $=1$ and disagree $=0$.

Although statement (4) is the one that is directly related to education, all statements reflect views on gender roles. Therefore, an alternative approach is to use all of the information in the five questions, instead of relying on the information in one question. Based on the answers given to the five questions, we generate a scale variable that acts as an index of traditionalism in views on gender roles. We define the scale variable as the first principal component of the responses to the five questions. The new variable is set to have a lowest value of zero; it has a maximum of 3.87 in 1998 and 4.14 in 2003. The means and standard deviations are shown in Table 1 (in 1998, mean: 1.50, standard deviation: 1.47; in 2003, mean: 1.15, standard deviation: 1.41). Compared to the indicator variable, the disadvantage of the scale variable is that it is related to aspects of gender roles that may not directly link to the education of children. The advantage is that the first principal component re-centers and summarizes data to capture the highest variance in the data. Since it re-centers data, it gives us information about the relative position of each respondent in the sample. If there is a tendency in the sample to answer the questions in a particular way, the scale variable will adjust for the tendency and show us the deviations from the tendency.

We re-estimate Eqs. (1) and (2) using the scale variable instead of the indicator variable to measure the views of the mother. We present in Tables 4 and 5 a summary of the results for Eqs. (1) and (2), respectively. We see that, although the magnitudes of the estimates change (as expected), our main findings are still valid. In other words, as can be seen in Table 4, the probability of dropping out during or after primary education is higher for girls than for boys, when mothers hold a more traditional view on gender roles (according to the coefficient estimates of the interaction term "Traditional $\times$ Female"). Beyond compulsory education (upon completion of junior high school), no difference is detected between girls and boys whose mothers hold a traditional view on gender roles.

In Table 5, column 1 shows that for boys, the reform decreased the dropout probability by $17.2 \%$ points (the coefficient estimate of "Post reform") if the mother has a nontraditional view and by $21.8 \%$ points (adding up the coefficient estimates of "Post reform" and "Post reform $\times$ Traditional") if the mother has a traditional view. In column 
Table 4 Mother's view on gender roles and children's educational attainment (TDHS 1998) (estimation of Eq. (1) using a scale variable to measure the views on gender roles)

\begin{tabular}{|c|c|c|c|c|c|c|}
\hline \multirow[t]{2}{*}{ Dependent variables } & \multicolumn{2}{|l|}{ (1) } & \multicolumn{2}{|l|}{ (2) } & \multicolumn{2}{|l|}{ (3) } \\
\hline & $\begin{array}{l}\text { Dropout } \\
\text { during } \\
\text { primary } \\
\text { school }\end{array}$ & $\begin{array}{l}\text { Dropout } \\
\text { during } \\
\text { primary } \\
\text { school }\end{array}$ & $\begin{array}{l}\text { Dropout } \\
\text { after } \\
\text { primary } \\
\text { school }\end{array}$ & $\begin{array}{l}\text { Dropout } \\
\text { after } \\
\text { primary } \\
\text { school }\end{array}$ & $\begin{array}{l}\text { Dropout } \\
\text { after junior } \\
\text { high school }\end{array}$ & $\begin{array}{l}\text { Dropout } \\
\text { after junior } \\
\text { high school }\end{array}$ \\
\hline Traditional (scale) & $\begin{array}{l}0.013 * * \\
(2.96)\end{array}$ & $\begin{array}{l}-0.009 \\
(1.94)\end{array}$ & $\begin{array}{l}0.067 * * * \\
(8.22)\end{array}$ & $\begin{array}{l}0.004 \\
(0.56)\end{array}$ & $\begin{array}{l}0.039 * * * \\
(3.56)\end{array}$ & $\begin{array}{l}0.014 \\
(1.19)\end{array}$ \\
\hline Traditional $\times$ female & $\begin{array}{l}0.040 * * * \\
(5.43)\end{array}$ & $\begin{array}{l}0.036 * * * \\
(5.32)\end{array}$ & $\begin{array}{l}0.058 * * * \\
(4.94)\end{array}$ & $\begin{array}{l}0.064 * * * \\
(6.07)\end{array}$ & $\begin{array}{l}-0.015 \\
(0.97)\end{array}$ & $\begin{array}{l}-0.009 \\
(0.58)\end{array}$ \\
\hline Female & $\begin{array}{l}0.038 * * * \\
(3.93)\end{array}$ & $\begin{array}{l}0.039 * * * \\
(4.23)\end{array}$ & $\begin{array}{l}0.157 * * * \\
(9.45)\end{array}$ & $\begin{array}{l}0.153 * * * \\
(10.60)\end{array}$ & $\begin{array}{l}-0.032 \\
(1.70)\end{array}$ & $\begin{array}{l}-0.016 \\
(0.87)\end{array}$ \\
\hline $\begin{array}{l}\text { Other controls in } \\
\text { Table } 2\end{array}$ & No & Yes & No & Yes & No & Yes \\
\hline$N$ & 3268 & 3268 & 2964 & 2964 & 1258 & 1258 \\
\hline Adjusted $R^{2}$ & 0.044 & 0.208 & 0.120 & 0.307 & 0.020 & 0.092 \\
\hline
\end{tabular}

See notes to Table 2

Table 5 Mother's view on gender roles and children's dropout probability (TDHS 2003) (estimation of Eq. (2) using a scale variable to measure the views on gender roles)

\begin{tabular}{|c|c|c|c|c|}
\hline \multirow{3}{*}{$\begin{array}{l}\text { Dependent variable: dropout after primary school } \\
\text { Samples } \\
\text { Traditional (scale) }\end{array}$} & \multirow{2}{*}{\multicolumn{2}{|c|}{$\frac{(1)}{\text { Born in 1983-1990 }}$}} & \multirow{2}{*}{\multicolumn{2}{|c|}{$\frac{(2)}{\text { Born in 1984-1989 }}$}} \\
\hline & & & & \\
\hline & $\begin{array}{l}0.048^{* * * *} \\
(4.33)\end{array}$ & $\begin{array}{l}0.022^{*} \\
(2.25)\end{array}$ & $\begin{array}{l}0.046 * * * \\
(3.74)\end{array}$ & $\begin{array}{l}0.018 \\
(1.66)\end{array}$ \\
\hline Traditional $\times$ female & $\begin{array}{l}0.078 * * * \\
(4.78)\end{array}$ & $\begin{array}{l}0.073 * * * \\
(4.97)\end{array}$ & $\begin{array}{l}0.080 * * * \\
(4.31)\end{array}$ & $\begin{array}{l}0.075 * * * \\
(4.53)\end{array}$ \\
\hline Female & $\begin{array}{l}0.061 * * \\
(2.73)\end{array}$ & $\begin{array}{l}0.088 * * * \\
(4.32)\end{array}$ & $\begin{array}{l}0.073 * * \\
(2.97)\end{array}$ & $\begin{array}{l}0.095 * * * \\
(4.15)\end{array}$ \\
\hline Post reform & $\begin{array}{l}-0.171^{* * *} \\
(11.03)\end{array}$ & $\begin{array}{l}-0.172 * * * \\
(11.29)\end{array}$ & $\begin{array}{l}-0.152 * * * \\
(8.73)\end{array}$ & $\begin{array}{l}-0.147 * * * \\
(8.59)\end{array}$ \\
\hline Post reform $\times$ female & $\begin{array}{l}0.031 \\
(1.20)\end{array}$ & $\begin{array}{l}0.017 \\
(0.70)\end{array}$ & $\begin{array}{l}0.015 \\
(0.52)\end{array}$ & $\begin{array}{l}0.002 \\
(0.08)\end{array}$ \\
\hline Post reform $\times$ traditional & $\begin{array}{l}-0.035 * * \\
(2.95)\end{array}$ & $\begin{array}{l}-0.046^{* * * *} \\
(4.22)\end{array}$ & $\begin{array}{l}-0.029 * \\
(2.16)\end{array}$ & $\begin{array}{l}-0.035^{* *} \\
(2.79)\end{array}$ \\
\hline Post reform $\times$ traditional $\times$ female & $\begin{array}{l}-0.037 \\
(1.88)\end{array}$ & $\begin{array}{l}-0.026 \\
(1.49)\end{array}$ & $\begin{array}{l}-0.043 \\
(1.90)\end{array}$ & $\begin{array}{l}-0.041^{*} \\
(2.02)\end{array}$ \\
\hline Other controls in Table 3 & No & Yes & No & Yes \\
\hline$N$ & 3690 & 3690 & 2783 & 2783 \\
\hline Adjusted $R^{2}$ & 0.110 & 0.230 & 0.101 & 0.219 \\
\hline
\end{tabular}

See notes to Table 3 
1, we can also see that the coefficient estimates of the interaction terms "Post reform $\times$ Female" and "Post reform $\times$ Traditional $\times$ Female" are both economically and statistically insignificant. Therefore, we conclude that on average the reform generated the same change in the dropout probability for girls and boys (this is true regardless of the views of their mothers). As a consequence, and as we reported before, the gender gap is not eliminated by the reform. The only difference from the earlier results is seen when the sample is restricted to 1984-1989 birth cohorts. According to the estimates shown in column 2 of the table, we see that for children whose mothers have a traditional view, the reform is associated with a greater decline in the dropout probability of girls than boys (in column 2, the coefficient estimate of the interaction term "Post reform $\times$ Traditional $\times$ Female" is negative and statistically significant at $5 \%$ ). Only in the restricted sample and only among mothers with a traditional view we find that the reform reduced the education gender gap.

Another concern about the measurement of views on gender roles might be that in conservative parts of Turkey a more patrilineal way of life exists, therefore it is possible that a mother's answer to questions on views on gender roles be influenced by their husbands or other men. The TDHS dataset has information about the presence of people other than the respondent herself during the time of the survey. Using the information, we test whether the responses of mothers taking the survey alone differ from the responses of mothers taking the survey in the presence of a man. In a regression of the traditional view indicator on a set of dummy variables that represent the presence of other people during the survey, we find that there is no statistically significant difference between the responses of

Table 6 Mother's view on gender roles and children's educational attainment (TDHS 1998) (estimation of Eq. (1) adding dummy variables for the presence of others as controls)

\begin{tabular}{|c|c|c|c|c|c|c|}
\hline \multirow[t]{2}{*}{ Dependent variable } & \multicolumn{2}{|l|}{ (1) } & \multicolumn{2}{|l|}{ (2) } & \multicolumn{2}{|l|}{ (3) } \\
\hline & $\begin{array}{l}\text { Dropout } \\
\text { during } \\
\text { primary } \\
\text { school }\end{array}$ & $\begin{array}{l}\text { Dropout } \\
\text { during } \\
\text { primary } \\
\text { school }\end{array}$ & $\begin{array}{l}\text { Dropout } \\
\text { after } \\
\text { primary } \\
\text { school }\end{array}$ & $\begin{array}{l}\text { Dropout } \\
\text { after } \\
\text { primary } \\
\text { school }\end{array}$ & $\begin{array}{l}\text { Dropout } \\
\text { after junior } \\
\text { high school }\end{array}$ & $\begin{array}{l}\text { Dropout } \\
\text { after junior } \\
\text { high school }\end{array}$ \\
\hline Traditional (indicator) & $\begin{array}{l}-0.001 \\
(0.05)\end{array}$ & $\begin{array}{l}-0.024 \\
(1.61)\end{array}$ & $\begin{array}{l}0.160 * * * \\
(5.76)\end{array}$ & $\begin{array}{l}0.021 \\
(0.82)\end{array}$ & $\begin{array}{l}0.109 * * \\
(2.86)\end{array}$ & $\begin{array}{l}0.061 \\
(1.62)\end{array}$ \\
\hline Traditional $\times$ female & $\begin{array}{l}0.112 * * * \\
(5.10)\end{array}$ & $\begin{array}{l}0.074 * * \\
(3.25)\end{array}$ & $\begin{array}{l}0.203 * * * \\
(5.18)\end{array}$ & $\begin{array}{l}0.181 * * * \\
(5.08)\end{array}$ & $\begin{array}{l}-0.003 \\
(0.06)\end{array}$ & $\begin{array}{l}-0.014 \\
(0.24)\end{array}$ \\
\hline Female & & $\begin{array}{l}0.025^{*} \\
(2.32)\end{array}$ & $\begin{array}{l}0.120 * * * \\
(6.40)\end{array}$ & $\begin{array}{l}0.125^{* * * *} \\
(7.71)\end{array}$ & $\begin{array}{l}-0.028 \\
(1.41)\end{array}$ & $\begin{array}{l}-0.007 \\
(0.37)\end{array}$ \\
\hline $\begin{array}{l}\text { Other controls in } \\
\text { Table } 2\end{array}$ & No & Yes & No & Yes & No & Yes \\
\hline $\begin{array}{l}\text { Controls for the } \\
\text { presence of others } \\
\text { during the survey }\end{array}$ & Yes & Yes & Yes & Yes & Yes & Yes \\
\hline$N$ & 3446 & 3446 & 3126 & 3126 & 1319 & 1319 \\
\hline Adjusted $R^{2}$ & 0.060 & 0.210 & 0.112 & 0.309 & 0.015 & 0.092 \\
\hline
\end{tabular}

See notes to Table 2. The variables to control for the presence of others include the dummies for the presence of a child younger than 10, the husband, the mother, the mother-in-law, other men and other women 
Table 7 Mother's view on gender roles and children's dropout probability (TDHS 2003) (estimation of Eq. (2) adding dummy variables for the presence of others as controls)

\begin{tabular}{|c|c|c|c|c|}
\hline \multirow{3}{*}{$\begin{array}{l}\text { Dependent variable: dropout after primary school } \\
\text { Samples } \\
\text { Traditional (indicator) }\end{array}$} & \multirow{2}{*}{\multicolumn{2}{|c|}{$\frac{(1)}{\text { Born in } 1983-1990}$}} & \multirow{2}{*}{\multicolumn{2}{|c|}{$\frac{(2)}{\text { Born in 1984-1989 }}$}} \\
\hline & & & & \\
\hline & $\begin{array}{l}0.191 * * * \\
(4.78)\end{array}$ & $\begin{array}{l}0.162 \text { *** } \\
(4.52)\end{array}$ & $\begin{array}{l}0.207 * * * \\
(4.68)\end{array}$ & $\begin{array}{l}0.174 * * * \\
(4.31)\end{array}$ \\
\hline Traditional $\times$ female & $\begin{array}{l}0.159^{*} \\
(2.52)\end{array}$ & $\begin{array}{l}0.108 \\
(1.86)\end{array}$ & $\begin{array}{l}0.126 \\
(1.80)\end{array}$ & $\begin{array}{l}0.072 \\
(1.10)\end{array}$ \\
\hline Female & $\begin{array}{l}0.030 \\
(1.22)\end{array}$ & $\begin{array}{l}0.069^{* *} \\
(3.07)\end{array}$ & $\begin{array}{l}0.050 \\
(1.86)\end{array}$ & $\begin{array}{l}0.086^{* * * *} \\
(3.48)\end{array}$ \\
\hline Post & $\begin{array}{l}-0.161^{* * * *} \\
(9.82)\end{array}$ & $\begin{array}{l}-0.150^{* * *} \\
(9.23)\end{array}$ & $\begin{array}{l}-0.139 * * * \\
(7.73)\end{array}$ & $\begin{array}{l}-0.121^{* * *} \\
(6.71)\end{array}$ \\
\hline Post reform $\times$ female & $\begin{array}{l}0.036 \\
(1.30)\end{array}$ & $\begin{array}{l}0.016 \\
(0.64)\end{array}$ & $\begin{array}{l}0.019 \\
(0.60)\end{array}$ & $\begin{array}{l}-0.003 \\
(0.11)\end{array}$ \\
\hline Post reform $\times$ traditional & $\begin{array}{l}-0.157 * * * \\
(3.71)\end{array}$ & $\begin{array}{l}-0.191 \text { *** } \\
(4.87)\end{array}$ & $\begin{array}{l}-0.161 * * * \\
(3.32)\end{array}$ & $\begin{array}{l}-0.187^{* * * *} \\
(4.11)\end{array}$ \\
\hline Post reform $\times$ traditional $\times$ female & $\begin{array}{l}0.006 \\
(0.08)\end{array}$ & $\begin{array}{l}0.036 \\
(0.53)\end{array}$ & $\begin{array}{l}0.012 \\
(0.15)\end{array}$ & $\begin{array}{l}0.036 \\
(0.47)\end{array}$ \\
\hline Other controls in Table 3 & No & Yes & No & Yes \\
\hline Controls for the presence of others during the survey & Yes & Yes & Yes & Yes \\
\hline$N$ & 3828 & 3828 & 2882 & 2882 \\
\hline Adj. $R^{2}$ & 0.128 & 0.230 & 0.116 & 0.221 \\
\hline
\end{tabular}

See notes to Table 3. The variables to control for the presence of others include the dummies for the presence of a child younger than 10, the husband, the mother, the mother-in-law, other men and other women

the two groups of mothers (regardless of whether we add the control variables listed in Tables 2 and 3, or not). The results are not presented here for brevity, but are available upon request.

We also test whether our baseline results are affected by the presence of others during the survey. We add to Eqs. (1) and (2) the dummy variables that represent the presence of other people during the survey. The results are shown in Tables 6 and 7. A comparison of Tables 6 to 2 and Tables 7 to 3 shows us that the estimates change little. Therefore, our main results are robust to the possible influence of others during the survey.

\section{Conclusions}

Turkey is one of the few developing countries where an education gender gap to the detriment of females still exists. In this study, we establish that having a traditional view on gender roles adversely affects the educational attainment of daughters. We find that for the birth cohorts that were not subject to the 1997 reform, the daughters of women who think that educating sons is more important than educating daughters are more likely to drop out during and after primary school compared to the sons of women with the same view. The 
adverse effect of a traditional view is detected at the primary school level and is independent of a large number of factors that we control for, including the birth order of the child, the region of residence, rural versus urban residence, parental education, ethnicity, household wealth, and household size. It also contrasts with the findings of an earlier study: “... effective enforcement of the state's policy of universal primary education for both boys and girls, such that even rural residence and traditional gender ideology and practices, both associated with gender inequality in post-primary schooling, do not prevent girls from finishing primary school" (Rankin and Aytaç 2006, p. 37).

Using the 1997 education reform that increased compulsory schooling from 5 to 8 years as a natural experiment, and comparing the birth cohorts that have been subject to the reform to those that have not, we show that the reform helped reduce school dropout rates across the country. This finding is certainly encouraging. However, we also find that reductions in school dropout rates were similar for boys and girls in the group of children whose mothers hold a traditional view as well as the group of children whose mothers hold a non-traditional view. This finding is somewhat disappointing in that the reform has not overcome gender gap in educational attainment. For the gender gap to close, we would expect a larger reduction in the dropout rates of girls, compared to boys.

Since extending the duration of compulsory schooling has not eliminated the gender gap in education in the parts of the country where traditionalism prevails, there is definitely a need for education policies specifically targeting girls in such families or communities. Critiques of the education reform argue that the extension of compulsory schooling was shunned by some segments of the society, because it came too abruptly with no public consultation or debate before the approval of the law. Another criticism was that the reform was one-dimensional. Some religious parents, who preferred religious schools at the junior high level, were reluctant to send their children to secular schools for a longer period of time [see, for example, Dulger (2004)].

Hence, although the reform had a significant impact on raising educational attainment of both boys and girls, it could have been even more successful had it been supplemented with additional policies to counteract the resistance of traditional parents to comply with the reform. In response to this resistance, civil society organizations supported by public institutions have initiated campaigns to encourage traditional families to provide their daughters with formal education. One such influential campaign called "Dad, Send me to School" was launched on April 23, 2005 by Dogan publishing and was later on supported by NGOs and public institutions. This campaign provided tuition scholarship to 10,500 girls in the last 10 years. An impact analysis of the reform before its implementation could have predicted that traditional families would resist the reform and hence such efforts could have accompanied the reform and contributed to its success.

Acknowledgments The authors highly appreciate the comments and suggestions from the journal editor and three anonymous referees. The authors are grateful to seminar participants at METU and to the participants of Bilkent University Annual Summer Workshop in Economics, the National Workshop on Economics of Education at Bogazici University and the ESPE Conference for comments and helpful suggestions. The usual disclaimer applies.

\section{References}

Acemoglu, D., \& Angrist, J. (2001). How large are human-capital externalities? evidence from compulsory schooling laws. In B. S. Bernanke \& K. Rogoff (Eds.), NBER macroeconomics annual (Vol. 15, pp. 9-74). Cambridge: MIT Press. 
Alat, Z., \& Alat, K. (2011). A qualitative study of parental resistance to girls' schooling. Educational Sciences: Theory \& Practice, 11(3), 1369-1373.

Alderman, H., Behrman, J. R., Ross, D. R., \& Sabot, R. (1996). Decomposing the gender gap in cognitive skills in a poor rural economy. The Journal of Human Resources, 31(1), 229-254.

Angrist, J. D., \& Krueger, A. (1991). Does compulsory school attendance affect schooling and earnings? Quarterly Journal of Economics, 106(4), 979-1014.

Aytac, I. A., \& Rankin, B. H. (2004). Modernity, traditionality, and junior high school attainment in Turkey. Social Indicators Research, 66, 267-282.

Bertrand, M. (2010). New perspectives on gender. In O. Ashenfelter \& D. Card (Eds.), Handbook of labor economics (Vol. 4B, pp. 1545-1592). Amsterdam: North-Holland.

Black, S., Devereux, P., \& Salvanes, K. (2008). Staying in the classroom and out of the maternity ward? The effect of compulsory schooling laws on teenage births. Economic Journal, 118, 1025-1054.

Brunello, G., Fort, M., \& Weber, G. (2009). Changes in compulsory schooling, education and the distribution of wages in Europe. Economic Journal, 119, 516-539.

Chou, S.-Y., Liu, J.-T., Grossman, M., \& Joyce, T. (2010). Parental education and child health: Evidence from a natural experiment in Taiwan. American Economic Journal: Applied Economics, 2(1), 33-61.

Devereux, P. J., \& Hart, R. A. (2010). Forced to be rich? Returns to compulsory schooling in Britain. The Economic Journal, 120, 1345-1364.

Dinçer, M. A., Kaushal, N., \& Grossman, M. (2013). Women's education: Harbinger of another spring? Evidence from a natural experiment in Turkey. NBER Working paper No. 19597.

Dulger, İ. (2004). Turkey: Rapid coverage for compulsory education-the 1997 basic education program. Scaling up poverty reduction: A global learning process and conference. Shanghai, China.

Eurostat. (2012). Key data on education in Europe 2012.

Farre, L., \& Vella, F. (2012). The intergenerational transmission of gender role attitudes and its implications for female labor force participation. Economica, 80, 1-29.

Fortin, N. (2005). Gender role attitudes and women's labour market outcomes across OECD countries. Oxford Review of Economic Policy, 21, 416-438.

Goldin, C., Katz, L. F., \& Kuziemko, I. (2006). The homecoming of American college women: The reversal of the college gender gap. Journal of Economic Perspectives, 20, 133-156.

Grant, M. J., \& Behrman, J. R. (2010). Gender gaps in educational attainment in less developed countries. Population and Development Review, 36(1), 71-89.

Gulesci, S., \& Meyersson, E. (2013). 'For the love of the republic' education, secularism, and empowerment. Working paper.

Herrera, L. (2004). Education, islam and modernity. Comparative Education Review, 48(3), 318-326.

Hisarciklilar, M., McKay, A., \& Wright, P. (2010). Gender based differences in educational achievement in Turkey: What has changed over time? Paper presented at the 30th annual conference of the MEEA. GA: Atlanta.

Hurriyet Daily News. (2015). Retrieved January 3, 2015, from http://www.hurriyetdailynews.com/motherhoodnot-a-career-for-men-turkish-health-minister.aspx?pageID=238\&nID=76409\&NewsCatID=341.

İlhan Tunç, A. (2009). Kız Çocuklarının Okula Gitmeme Nedenleri Van İli Örneği. Yüzüncü Yıl Üniversitesi, Eğitim Fakültesi Dergisi, 6(1), 237-269.

Institution of Population Studies; Hacettepe University; Macro International Inc. (1999). Turkish demographic and health survey 1998. TRHR41.DTA and TRIR41.DTA. Calverton, Maryland: Hacettepe University, Institution of Population Studies, Macro International Inc. ICF International, 1999.

Institution of Population Studies; Hacettepe University; Ministry of Health (Turkey). (2004). Turkish demographic and health survey 2003. TRHR4.DTA and TRIR4.DTA. Ankara, Turkey: Institute of Population Studies, Hacettepe University and Ministry of Health (Turkey). ICF International, 2004.

Kemptner, D., Jürges, H., \& Reinhold, S. (2011). Changes in compulsory schooling and the causal effect of education on health: Evidence from Germany. Journal of Health Economics, 30(2), 340-354.

Kirdar, M., Dayioglu, M., \& Koc, I. (2012). The effects of compulsory schooling laws on teenage marriage and births in Turkey. Working paper.

Kirdar, M., Dayioglu, M., \& Koc, I. (2013). Does longer compulsory education equalize schooling by gender and rural/urban residence? Working paper.

Korinek, K., \& Punpuing, S. (2012). The effect of household and community on school attrition: An analysis of Thai youth. Comparative Education Review, 56(3), 474-510.

Oreopoulos, P. (2006). Estimating average and local treatment effects of education when compulsory schooling laws really matter. American Economic Review, 96(1), 152-175.

Pekkarinen, T. (2012). Gender differences in education. IZA Discussion paper No. 6390.

Rankin, B. H., \& Aytaç, I. A. (2006). Gender inequality in schooling: The case of Turkey. Sociology of Education, 79(1), 25-43. 
Smits, J., \& Hoşgör, A. G. (2006). Effects of family background characteristics on educational participation in Turkey. 26. International Journal of Educational Development, 26, 545-560.

Sonmez, S. (2013). Primary education system in Ottoman Empire. International Journal of Humanities and Social Science, 3(5), 163-170.

Stash, S., \& Hannum, E. (2001). Who goes to school? Educational stratification by gender, caste, and ethnicity in Nepal. Comparative Education Review, 45(3), 354-378.

Tansel, A., \& Gungor, A. D. (2000). Provincial inequalities in school enrollments in Turkey. Economic research forum working paper 2003.

UNESCO. (2010). Education for all (EFA) global monitoring report. Reaching the marginalized. Paris: Oxford University Press.

Vella, F. (1994). Gender roles and human capital investment: The relationship between traditional attitudes and female labor market performance. Economica, 61, 191-211.

Zhang, Y., Kao, G., \& Hannum, E. (2007). Do mothers in rural China practice gender equality in educational aspirations for their children? Comparative Education Review, 51(2), 131-157. 